\title{
Conjunctival aerobic bacterial flora in healthy Silesian foals and adult horses in Poland
}

\author{
A. Zak ${ }^{1 *}$ (D, N. Siwinska ${ }^{1}$, M. Slowikowska ${ }^{1}$, H. Borowicz ${ }^{1}$, K. Ploneczka - Janeczko ${ }^{2}$, P. Chorbinski ${ }^{2}$ \\ and A. Niedzwiedz
}

\begin{abstract}
Background: Commensal bacterial and fungal flora of the conjunctival sac has been described in horses and other animals. The identification of commensal flora of the conjunctival sac may aid in the diagnosis of ocular inflammatory diseases, such as conjunctivitis or more severe ulcerative keratitis, common in horses. Moreover, damage of ocular protective barriers may lead to an opportunistic infection. The study was carried out in Silesian horses kept at a single breeding center in South-western Poland, in order to limit any breed-dependant and climate-dependant variables affecting the results. Following an ophthalmic examination that revealed no abnormalities, sterile swabs were collected from conjunctival sac in 26 adult horses and 11 foals. The obtained swabs were subjected to bacterial culture testing. In case of Staphylococcus spp. isolation, susceptibility to methicillin was evaluated.
\end{abstract}

Results: Forty- three bacterial isolates, representing eleven genera of bacteria were cultured from 30 (81\%) horses. Gram-positive bacteria were the dominant isolates (72\%) $(p<0.001)$. The most commonly isolated Gram-positive bacteria were Staphylococcus spp., while Moraxella spp. were the most frequently isolated Gram-negative bacteria. There was no significant influence of sex and age on the frequency and type of microbial isolates.

Conclusions: Commensal flora is present in the conjunctival sac of healthy horses in Poland. Age does not affect the abundance and type of microbial isolates.

Keywords: Horse, Conjunctival sac, Bacteriology

\section{Background}

Under physiological conditions, the surface of the eye is protected by a number of innate and adaptive immune systems, such as mucin and epithelium barrier functions, tear film that enables flushing of the ocular surface, antimicrobial tear components (lysozyme, beta-lysin, lactoferrin, blood cells, IgA), antigen presenting cells and special antigen-recognition receptors called Toll-like receptors [1-3]. Commensal flora also protects against microbial pathogens by producing antibacterial substances, limiting the surface of growth of other microorganisms and decreasing the nutrient content on the surface of the corneal

\footnotetext{
* Correspondence: agnieszka.zak@upwr.edu.pl

${ }^{1}$ Department of Internal Medicine and Clinic of Diseases of Horses, Dogs and Cats, Faculty of Veterinary Medicine, Wroclaw University of Environmental and Life Sciences, pl. Grunwaldzki 47, 50-366, Wroclaw, Poland
} Full list of author information is available at the end of the article and conjunctival epithelium [3-5]. Commensal bacterial and fungal flora of the conjunctival sac is commonly reported in horses and other animals [3, 5-14]. The most common Gram-positive bacterial isolates from the conjunctival sac in horses include Staphylococcus spp., Streptococcus spp., Corynebacterium spp. and Bacillus spp. [3, 5-9]. Gram-negative bacteria, such as Pseudomononas spp., Moraxella spp. and Acinetobacter spp., are much less common [6-8]. Studies on the commensal flora of the conjunctival sac report a mixed growth of at least two bacterial species, characterised by meagre growth often accompanied by fungi (i.e. Aspergillus spp., Penicillium spp., Fusarium spp., Cladosporium spp.) [6-8, 10, 11]. The study by Moore et al. 1988 did not find anaerobic bacteria in conjunctival swab cultures in healthy horses [5]. Damage of the protective barriers of the ocular

(c) The Author(s). 2018 Open Access This article is distributed under the terms of the Creative Commons Attribution 4.0 International License (http://creativecommons.org/licenses/by/4.0/), which permits unrestricted use, distribution, and reproduction in any medium, provided you give appropriate credit to the original author(s) and the source, provide a link to the Creative Commons license, and indicate if changes were made. The Creative Commons Public Domain Dedication waiver (http://creativecommons.org/publicdomain/zero/1.0/) applies to the data made available in this article, unless otherwise stated. 
surface, including injury to the cornea, may lead to the formation of pathological bacterial and fungal flora $[1,9$, 15]. Under pathological conditions, commensal flora may become opportunistic (eg. Pseudomonas aeruginosa) $[3,7$, 15, 16]. The most commonly isolated bacteria in the case of equine ulcerative keratitis include: Pseudomonas aeruginosa, Streptococcus equi subspecies zooepidemicus and Staphylococcus spp. [1, 16-18]. According to Moore et al., Gram-negative bacteria are isolated more commonly than Gram-positive bacteria in the course of ulcerative keratitis [5]. The identification of the physiological commensal flora in the conjunctival sac is essential in order to diagnose inflammatory ocular disorders and to choose the most effective antibacterial treatment prior to obtaining antibiogram results.

To date, no studies have been carried out in East-Central Europe assessing the commensal microbial flora of the conjunctival sac in horses. According to several studies, the geographical location, the climate zone and the age and breed of the horses may affect the type of bacterial flora in the conjunctival sac $[5,7]$. The presented study was carried out in one breed of horse, in animals stabled in a single facility in South-Western Poland, in order to eliminate any possible effects of breed and climate on the results. The aim of the study was to assess the presence of commensal flora in the conjunctival sac of healthy adult horses and foals and to determine the effect of sex, age and housing type on the amount of this flora. To the authors' best knowledge, there are no reports assessing commensal flora in the conjunctival sac of foals or the effect of age on the frequency and type of microbial isolates.

\section{Methods}

The study samples were collected from the "Książ Stallion Stud Farm" (coordinates: 5050'35.6”N 16¹7'58.4"E) on a single day in July 2017. Consent by the owner was obtained prior to sample collection. According to the present law in Poland (Experiments on Animals Act from January 15th 2015, Journal of Laws of the Republic of Poland from 2015, item. 266), the study did not require the approval of the Ethics Committee. The highest ambient temperature during the day was $18.5{ }^{\circ} \mathrm{C}$ during sample collection. According to the information provided by the owner of the horses, none of the animals had any ocular disorders and no systemic or topical ophthalmic drugs were used. A screening ophthalmic examination including the assessment of the eye accessory organs, the pupillary light reflex and the eye was carried out using a source of light (Ri-light, Riester, Jungingen, Germany). An assessment of the corneal surface, the anterior chamber, lens, the vitreous chamber and the ocular fundus with imaging of the optic disc was carried out using a direct ophthalmoscope (Ri-scope L2, Riester, Jungingen, Germany). The examination was performed by a qualified veterinary surgeon in a darkened environment. The cornea was not stained with fluorescein due to its potential bactericidal effect on the culture [19]. The clinical examination was normal. Thirty-seven horses were included in the study, which were divided into three groups: I. adult stallions (15 horses), with a mean age of 6.6 years (range: 3-16); II. adult mares (11 horses), with a mean age of 11.1 years (range: 5-18); III. healthy foals of both sexes up to 6 months old from mares from group II (11 horses), with a mean age of 4.1 months (range: $2-6$ months). The stallions in group I were kept in uniform conditions in separate stalls in one stable with one to two hours of training/ lunging per day. Groups II and III were stabled together. Groups II and III had a 9-10 h access to a pasture and spent the remaining time in a common stable without boxes. Straw (from the same source) was used as bedding in both stables, and the horses were fed hay ad libitum and oat according to their requirements. The swabs were collected from the right eye of each horse without sedation or local anaesthesia. The globe was retropulsed in order to visualise the conjunctiva of the lower eyelid and third eyelid, which was protruded. The sample was collected from the external surface of the third eyelid using a sterile swab (Sarstedt, Copan, Italia) covered by sterile saline. The swab was moved toward the conjunctival sac avoiding contact with the palpebral margin, eyelashes and vibrissae. The swabs were placed directly on an Amies (Sarstedt, Copan, Italia) transport medium and transported for analysis within an hour in temperature $4{ }^{\circ} \mathrm{C}$. The microbiological analysis was carried out at Epi-Vet, a veterinary diagnostic laboratory operating at the Department of Epizootiology with Clinic for Birds and Exotic Animals of the Wroclaw University of Environmental and Life Sciences, in accordance with the prevailing microbiological regulations (according ISO 9001:2008) [20].

\section{Obtaining isolates}

The samples were placed in a liquid medium containing broth and glucose (Oxoid, USA) and were then incubated at $37{ }^{\circ} \mathrm{C}$ for $24 \mathrm{~h}$ under aerobic conditions. Following incubation, the samples were cultured on a solid medium containing Columbia agar with 5\% sheep blood (Oxoid, USA), Mannitol Salt Agar (Oxoid, USA), MacConkey Agar with Crystal violet (Oxoid, USA). The plates were incubated at $37{ }^{\circ} \mathrm{C}$ for another $24 \mathrm{~h}$ under aerobic conditions. The colonial morphology was assessed using commercial biochemical tests, described below.

\section{Species strain identification}

In order to identify the species, the following tests were carried out: a. the oxidase test (with the use of a $1 \%$ solution of tetramethyl-p-phenylenediamine); b. the catalase test was performed with $3 \%$ hydrogen peroxide; c. 
detection of the Clumping Factor (CF) of Staphylococcus (using undiluted rabbit plasma). The species identification of the Staphylococcus isolates was determined using the RapID STAPH Plus (Remel Inc., USA) test. The species identification of non-fermenting Gram-negative bacterial isolates was determined using the RapID NF Plus test (RemelInc, USA).The assessment of Staphylococcus susceptibility to methicillin:

The susceptibility of the Staphylococcus spp. isolates to methicillin was examined using Mueller-Hinton agar (Oxoid, USA) and $30 \mu \mathrm{g}$ cefoxitin discs (Oxoid, USA), with incubation at $37^{\circ} \mathrm{C}$ for $24 \mathrm{~h} \mathrm{[21].}$

\section{Statistical analysis}

The Chi-squared test was used to assess the differences in proportions between the groups, and due to the small sample size, the Yate's correction was applied. All the analyses were performed at a 5\% significance level $(p=0,05)$ using the PQStat for Windows 1.6.2 software.

\section{Results}

Positive bacterial cultures were observed in 30 of the 37 healthy horses (81\%), including 12 of the 15 stallions $(80 \%)$, eight of the 11 mares (72\%) and 10 of the 11 healthy foals (91\%). No statistically significant relationship between the bacteriological result, the sex and the age of the horses was observed. Forty-three isolates were identified from the samples. The details of the bacterial isolates are presented in Table 1. Growth of a single species of bacteria was noted in 17 healthy horses $(56.7 \%$ positive bacteriological pathogen detection), including five stallions, six mares and six healthy foals. Mixed bacterial growth was observed in 13 healthy horses (43.3\% positive bacteriological pathogen detection), including in seven stallions, two mares and four foals. The complete results, including the age and sex of the animals, is presented in Table 2 . There was no statistically significant difference between the type of bacterial growth, the sex and the age of the animals. There were significantly more Gram-positive bacteria (31 isolates - $72 \%)$ than Gram-negative bacteria (12 isolates - 28\%) $(p<0.001)$. No statistically significant difference between the growth of Gram-positive and Gram-negative bacteria and the age and sex of the horses was found. The same bacterial isolates were found in two out of 11 mare-foal pairs. The detailed results are presented in Table 3. Most of the Staphylococcus bacteria were coagulase-negative (three isolates were of undetermined morphology using commercial biochemical tests) and no methicillin-resistant Staphylococcus spp. strains were observed.

\section{Discussion}

The Silesian horse is a breed of warmblood horse native to Upper and Lower Silesia in Poland and is part of the Conservation Program of Genetic Diversity in Farm Animals in Poland. The obtained results are consistent with similar studies in horses in other geographical regions. Positive bacteriological pathogen detection and bacterial culture was present in $81 \%$ of the healthy horses. Other studies often reported less frequent bacterial growth in samples from conjunctival sac, occurring in 30 to $52 \%$ of the healthy horses $[6,8]$. In the study by Gemensky-Metzler et al. 2005 bacterial isolates were presented more frequent: in $78 \%$ of the corneal swabs and $90 \%$ of the conjunctival sac swabs [3].

This study confirmed the tendency toward a more frequent Gram-positive bacterial culture than a Gram-negative bacterial culture of conjunctival sac swabs from healthy horses [3, 5-9]. In the present study, $66.67 \%$ of the isolates from adult horses and $71.43 \%$ of the isolates from foals were

Table 1 Bacterial isolates from normal eyes

\begin{tabular}{|c|c|c|c|}
\hline Isolate & Gram positive/ Gram negative & Total number of isolates & Percent of total isolates \\
\hline Staphylococcus sciuri ${ }^{a}$ & Positive & 16 & $37.2 \%$ \\
\hline Staphylococcus xylosus ${ }^{a}$ & Positive & 9 & $21.0 \%$ \\
\hline Staphylococcus spp.* ${ }^{* b}$ & Positive & 4 & $9.3 \%$ \\
\hline Staphylococcus simulans ${ }^{a}$ & Positive & 1 & $2.3 \%$ \\
\hline Brevibacterium diminuta & Positive & 1 & $2.3 \%$ \\
\hline Moraxella lacunata & Negative & 5 & $11.6 \%$ \\
\hline Pseudomonas aeruginosa & Negative & 1 & $2.3 \%$ \\
\hline Sphingomonas paucimobilis & Negative & 2 & $4.7 \%$ \\
\hline Burkholderia cepacia & Negative & 2 & $4.7 \%$ \\
\hline Comamonas acidovorans & Negative & 1 & $2.3 \%$ \\
\hline Chryseobacterium meningosepticum & Negative & 1 & $2.3 \%$ \\
\hline Total & & 43 & $100 \%$ \\
\hline
\end{tabular}

(*not subjected to further strain identification)

aMSCNS- methicillin-susceptible coagulase-negative Staphylococcus)

${ }^{\mathrm{b}} \mathrm{MSS}$ - methicillin-susceptible Staphylococcus 
Table 2 Bacterial isolates from normal eyes

\begin{tabular}{|c|c|c|c|c|}
\hline Groups & Group I - stallions & Group II - mares & Group I and II - adult horses & Group III foals \\
\hline Number of horses & 15 & 11 & 26 & 11 \\
\hline No growth & 3 & 3 & 6 & 1 \\
\hline Number of isolates & 19 & 10 & 29 & 14 \\
\hline Isolates: & $\begin{array}{l}\text { Number of } \\
\text { isolates/\% isolates }\end{array}$ & $\begin{array}{l}\text { Number of } \\
\text { isolates/\% isolates }\end{array}$ & $\begin{array}{l}\text { Number of } \\
\text { isolates/\% isolates }\end{array}$ & $\begin{array}{l}\text { Number of } \\
\text { isolates/\% isolates }\end{array}$ \\
\hline Staphylococcus sciuri ${ }^{a}$ & $8 / 42.1 \%$ & $4 / 40 \%$ & $12 / 41.4 \%$ & $4 / 28.6 \%$ \\
\hline Staphylococcus xylosus ${ }^{a}$ & $2 / 10.5 \%$ & $4 / 40 \%$ & $6 / 20.7 \%$ & $3 / 21.45 \%$ \\
\hline Staphylococcus spp. ${ }^{* b}$ & $2 / 10.5 \%$ & 0 & $2 / 6.9 \%$ & $2 / 14.3 \%$ \\
\hline Staphylococcus simulans ${ }^{a}$ & 0 & 0 & 0 & $1 / 7.1 \%$ \\
\hline Brevibacterium diminuta & 0 & 0 & 0 & $1 / 7.1 \%$ \\
\hline Moraxella lacunata & $3 / 15.7 \%$ & 0 & $3 / 10.3 \%$ & $2 / 14.3 \%$ \\
\hline Pseudomonas aeruginosa & $1 / 5.3 \%$ & 0 & $1 / 3.45 \%$ & 0 \\
\hline Sphingomonas paucimobilis & $1 / 5.3 \%$ & $1 / 10 \%$ & $2 / 6.9 \%$ & 0 \\
\hline Burkholderia cepacia & $1 / 5.3 \%$ & 0 & $1 / 3.45 \%$ & $1 / 7.1 \%$ \\
\hline Comamonas acidovorans & $1 / 5.3 \%$ & 0 & $1 / 3.45 \%$ & 0 \\
\hline $\begin{array}{l}\text { Chryseobacterium } \\
\text { meningosepticum }\end{array}$ & 0 & $1 / 10 \%$ & $1 / 3.45 \%$ & 0 \\
\hline
\end{tabular}

(*not subjected to further strain identification)

${ }^{a}$ MSCNS- methicillin-susceptible coagulase-negative Staphylococcus)

${ }^{\mathrm{b}} \mathrm{MSS}$ - methicillin-susceptible Staphylococcus

from the Staphylococcus spp. genus. This finding was confirmed in previous studies, where Staphylococcus spp. was reported to be the most prevalent or the second most prevalent type of isolated bacteria [3, 5-8]. However, this microbial species was much more common in the present

Table 3 Bacterial isolates from healthy mares and their folas

\begin{tabular}{|c|c|c|}
\hline pair nr & mare isolates & foal isolates \\
\hline 1. & S. sciuri ${ }^{a}$ & S. simulans ${ }^{\mathrm{b}}$ \\
\hline 2. & S.sciuri ${ }^{\mathrm{a}}$ & $\begin{array}{l}\text { S. xylosus }{ }^{c} \\
\text { B. cepacia }\end{array}$ \\
\hline 3. & No growth & $\begin{array}{l}\text { S. sciuria } \\
\text { M. lacunata }\end{array}$ \\
\hline 4. & No growth & S. xylosus ${ }^{c}$ \\
\hline 5. & $\begin{array}{l}\text { S. } x \text { losus } \\
\text { S. paucimobilis }\end{array}$ & S. sciuri $i^{a}$ \\
\hline 6. & S. xylosus ${ }^{c}$ & Staphylococcus spp.' \\
\hline 7. & S. $x y l o s u s^{c}$ & no growth \\
\hline 8. & S. sciuri ${ }^{\mathrm{a}}$ & S. sciuri ${ }^{\mathrm{a}}$ \\
\hline 9. & S. sciuri ${ }^{\mathrm{a}}$ & Staphylococcus spp.' \\
\hline 10. & no growth & $\begin{array}{l}\text { S. sciuria } \\
\text { B. diminuta }\end{array}$ \\
\hline 11. & $\begin{array}{l}\text { S. } \text { xylosus }^{\mathbf{c}} \\
\text { Ch. meningosepticum }\end{array}$ & $\begin{array}{l}\text { S. xylosus } \\
\text { M. lacunata }\end{array}$ \\
\hline
\end{tabular}

Bacterial isolates from healthy mares and their foals: the overlapping results are presented in bold (legend: ${ }^{\mathrm{a} S t a p h y l o c o c c u s ~ s c i u r i, ~}{ }^{\mathrm{b}}$ Staphylococcus simulans, 'Stapylococcus xylosus, ${ }^{\mathrm{d}}$ Burkholderia cepacia, ${ }^{\mathrm{e}}$ Moraxella lacunata ${ }^{\mathrm{f}}$ Sphingomonas paucimobilis, ${ }^{\mathrm{g}}$ Brevibacterium diminuta, ${ }^{\mathrm{h}} \mathrm{Chryseobacterium}$ meningosepticum, 'not subjected to further analysis) study than in previous studies [3,5-8]. The cause of varying dominant isolates between studies is not clear, although hypothetically it may be associated with different maintenance conditions, such as different bedding, hay, weather and climate. The majority of the isolated Staphylococcus spp. bacteria were coagulase-negative. Coagulase-negative Staphylococci (CNS) are considered non-pathogenic commensal bacteria, although it is currently believed that they may be a cause of opportunistic infections [22]. All of the isolates were methicillin- sensitive using the cefoxitin disc susceptibility test [21]. According to literature, methicillin-resistant Staphylococcus aureus (MRSA) was isolated in one case of ulcerative keratitis in a horse in Japan [23]. Methicillin-resistant Staphylococci (MRS) were also isolated from a horse with a surgical wound complication as well as from the nares and skin of healthy horses [24-26]. MRS are also a cause of ocular disease in humans $[27,28]$.

The second most common bacterial isolate was Moraxella spp. (11.6\%), all of which are identified as Moraxella lacunata, which are gram-negative coccobacilli responsible for opportunistic infections. This finding has been confirmed in literature, where Moraxella spp. was reported to be the most prevalent or the second most prevalent type of isolated gram-negative bacteria $[3,5$, 7]. According to Moore et al. 1983, the majority of commensal flora is formed by Gram-positive bacteria, while Gram-negative microorganisms usually cause septic infections [16]. In the study by Sauer et al. 2003 Pseudomonas aeruginosa was the most frequently isolated 
pathogen in the case of equine bacterial ulcerative keratitis [17]. Pseudomonas aeruginosa is an opportunistic bacterium considered to be the most virulent corneal pathogen, with the capacity to produce proteases and exotoxins and causing serious damage of the corneal epithelium and endothelium $[1,15]$. In the present study, $P$. aeruginosa was isolated from one healthy horse. $P$. aeruginosa showed mixed growth with Staphylococcus sciuri, suggestive of a commensal infection. However, other authors reported that Gram-positive bacteria, such as Streptococcus equi subsp. zooepidemicus and Staphylococcus aureus, were isolated more frequently from cases of ulcerative keratitis than the Gram-negative $P$. aeruginosa $[1,15,18,29,30]$. The commensal flora isolated from the conjunctival sac in the present study was also isolated in cases of ulcerative keratitis, i.e. Staphylococcus xylosus, Staphylococcus sciuri, Sphingomonas paucimobilis (isolated by Hidaka et al. [18]) and Burkholderia cepacia (isolated by Sauer et al. 2003) [17, 18]. This confirmed the hypothesis that commensal bacteria may act as pathogens in case of damage of the ocular barrier. One must also keep in mind that bacterial ulcerative keratitis should be diagnosed based on a swab obtained directly from the ulcer, as the conjunctival flora is not directly related to the corneal flora.

There were no statistically significant differences between the number of isolates, the age and the similarity of the isolates between the mother-foal pairs. This suggests that foals above two months of age develop their own commensal flora, independent of their mothers' flora. Mycological research carried out by Sgorbini et al. 2008 on newborn foals reported a commensal flora immediately after delivery [10]. Those authors found this flora to be diverse in the first month of life, which may be associated with later bacterial colonisation of the conjunctival sac [10]. In order to understand the detailed mechanisms of conjunctival sac bacterial colonisation, further studies assessing conjunctival swabs immediately after birth and during the first days of life are needed. Studies carried out on newborn children immediately after delivery revealed more prevalent conjunctival sac bacterial isolates in newborns born vaginally compared with those delivered by caesarean [31]. However, the number of bacterial isolates from the conjunctival sac was similar in both groups in the second day of life [31]. This indicates contamination of the newborn conjunctival sac with vaginal commensal bacteria, as well as subsequent colonisation with bacteria from the children's carers and from their surroundings [31].

The presence of insects in stables, which often have contact with horse eyes and mechanically transmit microorganisms, may be an important factor contributing to bacterial colonisation of the equine conjunctival sac. In the study by Butler et al. 2010, Staphylococcus sciuri and Staphylococcus xylosus, which were isolated from the horses in the present study, were isolated from the surface of the housefly (Musca domestica L) [32]. The study by Andrew et al. 2003 and Moore et al. 1988 revealed no impact of the season and surroundings on the conjunctival sac bacterial flora [5, 7]. In the presented study, the horses from group I spent less time on pasture than horses from group II and III. However, this did not affect the number of microbiological isolates.

\section{Conclusions}

The commensal flora in the equine conjunctival sac of horses in Poland may vary despite the horses living in uniform environment conditions. In addition, foals older than two months of age have fully developed bacterial commensal flora, independent of the mothers' flora.

\section{Abbreviations \\ CNS : coagulase-negative Staphylococcus; MRS : methicillin-resistance Staphylococcus; MSCNS : methicillin-susceptible coagulase-negative Staphylococcus}

\section{Acknowledgements}

We are grateful to Angelika Bryla and Kinga Malewska, students of Faculty of Veterinary Medicine, Wroclaw University of Environmental and Life Sciences for help during sample collecting.

\section{Funding}

The research was financed from statutory research no B010/0017/17 at Department of Epizootiology with Clinic for Birds and Exotic Animals, Wroclaw University of Environmental and Life Sciences.

\section{Availability of data and materials}

The datasets generated during and/or analysed during the current study available from the corresponding author on reasonable request.

\section{Authors' contributions}

$A \dot{Z}$ participated in the design of the study and was a major contributor in writing the manuscript. NS, MS, HB participated in the design of the study, in the collection of the samples and in the analysis and the interpretation of data. KP-J, PC and AN participated in the design of the study and performed the statistical analysis. KP-J, PC and AN conceived the study, participated in its design and coordination and helped to draft the manuscript. All authors were involved in a continuous discussion regarding the manuscript. All authors read and approved the final manuscript.

\section{Ethics approval and consent to participate}

In accordance with the Experiments on Animals Act from January 15th 2015 (Journal of Laws of the Republic of Poland, 2015, item. 266), concerning the welfare of the animals used for research or teaching purposes, the provisions shall not apply to: 1. veterinary services as defined by the Act from December 18th 2003 concerning veterinary practices (Journal of Laws from 2004, No. 11 item 95 as amended in item 3), as well as agricultural activity, raising and breeding livestock according to the Animal Welfare Act, not designed to carry out medical procedures; 2 . clinical veterinary studies carried out according to Article 37ah-37ak of the Act from September 6th 2001 - Pharmaceutical Law (Journal of Laws from 2008, No. 45, item 271 as amended in item 4); 3. activity aimed at identifying animals; 4 . capturing wild animals for biometric and systematic assessment; 5 . veterinary procedures which to not cause pain, suffering, distress or permanent health impairment equal to or more invasive than the insertion of a needle. Hence, the study entitled "The bacteriological examination of conjunctival swabs in healthy Silesian adult horses and foals." does not require the approval of the Ethics Committee. All procedures were performed during the study with owner consent.

Consent for publication

Not applicable. 


\section{Competing interests}

The authors declare that they have no competing interests. None of the aforementioned companies had any direct or indirect involvement in the development of the manuscript and the works reflects the opinions of the authors.

\section{Publisher's Note}

Springer Nature remains neutral with regard to jurisdictional claims in published maps and institutional affiliations.

\section{Author details}

'Department of Internal Medicine and Clinic of Diseases of Horses, Dogs and Cats, Faculty of Veterinary Medicine, Wroclaw University of Environmental and Life Sciences, pl. Grunwaldzki 47, 50-366, Wroclaw, Poland. ${ }^{2}$ Department of Epizootiology with Clinic for Birds and Exotic Animals, Wroclaw University of Environmental and Life Sciences, pl. Grunwaldzki 45, 50-366, Wroclaw, Poland.

Received: 29 May 2018 Accepted: 24 August 2018

Published online: 31 August 2018

\section{References}

1. Keller RL, Hendrix DVH. Bacterial isolates and antimicrobial susceptibilities in equine bacterial ulcerative keratitis (1993-2004). Equine Vet J. 2005;37(3): 207-11.

2. Gilger BC. Immunology of the ocular surface. Vet Clin Small Anim. 2008;38: 223-31

3. Gemensky-Metzler AJ, Wilkie DA, Kowalski JJ, Schmall LM, Willis A, Yamagata M. Changes in bacterial and fungal ocular flora of clinically normal horses following experimental application of topical antimicrobial or antimicrobialcorticosteroid ophthalmic preparations. Am J Vet Res. 2005;66:800-11.

4. Halbert SP. Inhibitory properties of the ocular flora. In: Lacatcher-Khorazo D, Seegal BC, editors. Microbiology of the eye. St Louis: Mosby; 1972. p. 24-40.

5. Moore CP, Heller N, Majors L, Whitley RD, Burgees EC, Weber J. Prevalence of ocular microorganisms in hospitalized and stabled horses. Am J Vet Res. 1988:49:773-9

6. Whitley RD, Burgess EC. Moore CP. Microbial isolates of the normal equine eye. Equine vet J. Suppl. 1983;2:138-40.

7. Andrew SE, Nguyen A, Jones GL, Brooks DE. Seasonal effects on the aerobic bacterial and fungal conjunctival flora of normal thoroughbred brood mares in Florida. Vet Ophthalmol. 2003;6:45-50.

8. Johns IC, Baxter K, Booler H, Hicks C, Menzies-Gow N. Conjunctival bacterial and fungal flora in healthy horses in the UK. Vet Ophthalmol. 2011;14(3):195-9.

9. Whitley RD, Moore CP. Microbiology of the equine eye in health and disease. Vet Clin N Am-Large. 1984;6(3):451-66.

10. Sgorbini M, Barsotti G, Nardoni S, Mancianti F, Rossi S, Corazza M. Fungal Flora of normal eyes in healthy newborn foals living in the same stud farm in Italy. J Equine Vet Sci. 2008:28(9):540-3.

11. Rosa M, Cardozo LM, Pereira J, Brooks DE, Martins ALB, Florido PSS, Stussi JSP. Fungal flora of normal eyes of healthy horses from the state of Rio de Janeiro, Brazil. Vet Ophthalmol. 2003;6(1):51-5.

12. Kiełbowicz Z, Płoneczka-Janeczko K, Bania J, Bierowiec K, Kiełbowicz M. Characteristics of the bacterial flora in the conjunctival sac of cats from Poland. J Small Anim Pract. 2015;56:203-6.

13. Urban M, Wyman M, Rheins M, Marraro RV. Conjunctival flora of clinically normal dogs. JAVMA. 1972;161:201-6.

14. Wilcox GE. Bacterial flora of the bovine eye with special reference to the Moraxella and Neisseria. Aust Vet J. 1970;46:253-7.

15. Leigue L, Montiani-Ferreirm F, Moore BA. Antimicrobial susceptibility and minimal inhibitory concentration of Pseudomonas aeruginosa isolated from septic ocular surface disease in different animal species. Open Veterinary Journal. 2016;6(3):215-22.

16. Moore $\mathrm{CP}$, Fales $\mathrm{WH}$, Whittington $\mathrm{P}$, Bauer L. Bacterial and fungal isolates from Equidae with ulcerative keratitis. JAVMA. 1983;182(6):600-3.

17. Sauer $P$, Andrew SE, Lassaline M, Gelatt KN, Denis HM. Changes in antibiotic resistance in equine bacterial ulcerative keratitis (1991-2000): 65 horses. Vet Ophthalmol. 2003;6(4):309-13.

18. Hidaka S, Kobayashi M, Ando K, Fujji Y. Efficacy and safety of lomefloxacin on bacterial extraocular disease in the horse. J Vet Med Sci. 2015;77(7):829-35.

19. Malhotra S, Kaur N, Mehta DK. Bactericidal effect of trypan blue and fluorescein sodium in ophthalmic practice. Nepal J Ophthalmol. 2012;4(1):80-3.
20. Szewczyk ME. Diagnostyka bakteriologiczna. Warszawa: Wydawnictwo Naukowe PWN; 2013.

21. Pourmand MR, Hassanzedeh S, Mashhadi R, Askari E. Comparison of four diagnostic methods for detection of methicillin resistant Staphylococcus aureus. Iranian Journal of Microbiology. 2014;6(5):341-4.

22. Kloos WE, Bannerman TL. Update of clinical significance of coagulasonegative Staphylococci. Clinical Microbiology Reviews. 1994;7(1):177-14023.

23. Kuroda T, Kinoshita Y, Niwa H, Mizobe F, Ueno T, Kuwano A, Hatazoe T, Hobo S. Methicillin-resistant Staphylococcus aureus ulcerative keratitis in a thoroughbred racehorse. J Equine Sci. 2015;26(3):95-8.

24. Karakulska J, Fijałkowski K, Nawrotek P, Pobucewicz A, Poszumski F, Identification C-FD. Methicillin resistance of coagulase-negative staphylococci isolated from nasal cavity of healthy horses. J Microbiol. 2012; 50(3):444-51.

25. Yasuda R, Kawano J, Onda H, Takagi M, Shimizu A, Anzai T. Methicillinresistant coagulase-negative staphylococci isolated from healthy horses in Japan. AJVR. 2000;61(11):1451-5.

26. Hartmann FA, Troslte SS, Klohnen AA. Isolation of methicillin-resistant Staphylococcus aureus from a postoperative wound infection in a horse. J Am Med Assoc. 1997;211:590-2.

27. Shanmuganathan VA, Armstrong M, Buller A, Tullo AB. External ocular infections due to methicillin-resistant Staphylococcus aureus (MRSA). Eye. 2005;19:284-91.

28. Blomquist PH. Methicillin-resistant Staphylococcus aureus infections of the eye and orbit. Trans Am Ophthalmol Soc. 2006;104:322-45.

29. Brooks DE, Andrew SE, Biros DJ, Denis HM, Cutler TJ, Strubbe DT, Gelatt KN. Ulcerative keratitis caused by beta-hemolytic Streptococcus equi in 11 horses. Vet Ophthalmol. 2000;3:121-5.

30. McLaughlin SA, Brightman AH, Helper LC, Manning JP, Tomes JE. Pathogenic bacteria and fungi associated with extraocular disease in the horse. J Am Vet Med Assoc. 1983;182(3):241-2.

31. Lee PW, Jun AK, Cho BC. A study of microbial flora of conjunctival sac in newborns. Korean J Ophthalmol. 1989:3(1):33-7.

32. Butler JF, Garcia-Maruniak A, Meek F, Maruniak JE. Wild Florida house flies (Musca Domestica) as carriers of pathogenic bacteria. Fla Entomol. 2010; 93(2):218-23.

\section{Ready to submit your research? Choose BMC and benefit from:}

- fast, convenient online submission

- thorough peer review by experienced researchers in your field

- rapid publication on acceptance

- support for research data, including large and complex data types

- gold Open Access which fosters wider collaboration and increased citations

- maximum visibility for your research: over $100 \mathrm{M}$ website views per year

At BMC, research is always in progress.

Learn more biomedcentral.com/submissions 